\title{
Perbandingan antara penggunaan karbonat apatit dan hidroksi apatit pada proses penutupan defek kalvaria dengan menggunakan plasma kaya trombosit
}

\author{
${ }^{1}$ Atmaja Surbakti, ${ }^{2}$ Maximillian Ch. Oley, ${ }^{2}$ Eko Prasetyo
}

\author{
${ }^{1}$ Program Studi Ilmu Bedah Fakultas Kedokteran Universitas Sam Ratulangi Manado \\ ${ }^{2}$ KSM Ilmu Bedah Divisi Bedah Saraf RSUP Prof. Dr. R. D. Kandou Manado \\ Email: atmaja_bedah@yahoo.co.id
}

\begin{abstract}
Carbonate hydroxy apatite (CHA) and hydroxyapatite (HA) are calcium phosphate biomaterials for bone substitute which have the characteristics of biocompatibility, bioactivity, and osteoconductivity. Platelet rich plasma (PRP) has platelet concentration of 3-5 times above normal and contains growth factor. This study was aimed to compare the effectiveness of CHAPRP and HA-PRP in the occlusion of calvaria deffect. This was a descriptive observational study. Subjects were 18 Wistar rats (Rattus norvegicus), aged 20-22 weeks, weighing 350-400 g. PRP was processed from $3 \mathrm{ml}$ of intracardiac blood. Calvaria defect of $3 \mathrm{~mm}$ diameter was performed as a burr hole. Subjects were divided into 2 groups. Group 1 was treated with CHA-PRP meanwhile group 2 was treated with HA-PRP. The rats were terminated at weeks 2, 3, and 4, then the calvaria bone tissue was evaluated histopathologically. The results showed that at week-2, group 1 had inflammatory cells of $80-90 \%$ and immature bone formation of $10 \%$, while group 2 had inflammatory cells of $60-70 \%$ and immature bone formation of $5 \%$. At week-3, group 1 had inflammatory cells of $80 \%$ and immature bone formation of $10-45 \%$ while group 2 had inflammatory cells of $60-70 \%$ and immature bone formation of 10-20\%. At week-4, group 1 had inflammatory cells of $80-90 \%$ and immature bone formation of $45-90 \%$ while group 2 had inflammatory cells of $20-70 \%$ and immature bone formation of $15-55 \%$. Conclusion: In rats (Rattus norvegicus) with calvaria defects, CHA-PRP treatment could accelerate the occlusion process better than HA-PRP.
\end{abstract}

Kata kunci: carbonate hydroxy apatite, hydroxyapatite, platelet rich plasma

\begin{abstract}
Abstrak: Karbonat hidroksi apatit (KHA) dan hidroksi apatit (HA) merupakan biomaterial kalsium fosfat pengganti tulang yang bersifat biokompatibilitas, bioaktivitas, osteokonduktif. Plasma kaya trombosit (PKT) mempunyai konsentrasi trombosit 3-5 kali di atas normal dan mengandung faktor pertumbuhan. Penelitian ini bertujuan untuk membandingkan pengaruh pemberian KHA-PKT dan HA-PKT pada proses penutupan defek kalvaria tikus. Jenis penelitian ialah deskriptif observasional. Subyek penelitian berupa 18 ekor tikus putih (Rattus norvegicus) galur Wistar, umur 20-22 minggu, berat badan 350-400 gr. Pengambilan darah tikus $3 \mathrm{cc}$ intrakardiak diolah menjadi PKT. Defek kalvaria dibuat berbentuk burr hole diameter $3 \mathrm{~mm}$. Subyek dibagi atas dua kelompok. Kelompok 1 diberikan KHA-PKT sedangkan kelompok 2 diberikan HA-PKT. Tikus diterminasi pada minggu ke-2, 3, dan 4 dan jaringan tulang kalvaria dievaluasi secara histopatologik. Hasil penelitian memperlihatkan di minggu ke-2, pada kelompok 1 terdapat infiltrasi sel radang 80-90\% dan pembentukan tulang imatur 10\% sedangkan kelompok 2 infiltrasi sel radang 60-70\% dan pembentukan tulang imatur 5\%. Di minggu ke-3, pada kelompok 1 terdapat infiltrasi sel radang $80 \%$ dan pembentukan tulang imatur 10-45\% sedangkan kelompok 2 infiltrasi sel radang 60-70\% dan pembentukan tulang imatur 10-20\%. Di minggu ke-4, pada kelompok 1 terdapat infiltrasi sel radang 80-90\% dan pembentukan tulang imatur $45-90 \%$ sedangkan kelompok 2 infiltrasi sel radang $20-70 \%$ dan pembentukan tulang imatur 15-55\%. Simpulan: Pada tikus (Rattus norvegicus) dengan defek kalvaria, pemberian KHA-PKT dapat lebih mempercepat proses penutupan defek dibandingkan pemberian HA-PKT.

Kata kunci: karbonat hidroksi apatit, hidroksi apatit, plasma kaya trombosit
\end{abstract}


Cedera kepala adalah cedera yang secara langsung mengenai kepala yang mengakibatkan luka di kulit kepala, fraktur tulang tengkorak, dan perdarahan intrakranial berupa perdarahan ekstradural maupun intradural. ${ }^{1}$ Penyebab cedera kepala dapat berupa trauma benda tumpul dan benda tajam. Benda tumpul berkaitan dengan kecelakaan lalu lintas, jatuh, dan pukulan benda tumpul, sedangkan benda tajam berkaitan dengan luka bacok dan tembakan. Penyebab cedera kepala terbanyak ialah kecelakaan lalu lintas (KLL) berupa kecelakaan sepeda motor. Hal ini disebabkan karena pengendara sepeda motor tidak menggunakan helm yang memenuhi standar, tidak memakai helm, dan kurangnya kesadaran untuk menjaga keselamatan di jalan raya. Di Indonesia, pada tahun 2005 angka kematian akibat trauma kepala berkisar $6,2-11,2 \%{ }^{2}$

Defek kalvaria adalah hilangnya tulang kepala yang dapat terjadi karena trauma langsung atau prosedur operasi pada patologi intrakranial. Defek kalvaria akibat trauma langsung berupa avulsi sedangkan defek kalvaria karena prosedur operasi dapat berupa kraniektomi. Pada saat benturan di kepala dapat terjadi perdarahan intrakranial baik berupa perdarahan ekstradural maupun intradural serta fraktur pada kalvaria yang memerlukan tindakan segera berupa dekompresi yang disebut kraniektomi. Tindakan untuk menutup defek kalvaria karena tindakan kraniektomi disebut kranioplasti. ${ }^{3}$ Penutupan defek kalvaria dapat menggunakan antara lain titanium mesh tetapi bersifat tidak menyerap. ${ }^{4}$

Kerusakan pada organ tulang merupakan masalah kesehatan yang serius karena tulang merupakan salah satu organ tubuh yang sangat penting bagi manusia sehingga bila terjadi kerusakan maka fungsi kerja dari tubuh akan terhambat. Dalam menangani kerusakan pada tulang tersebut dibutuhkan suatu material yang tepat untuk implantasi tulang. Material pengganti tulang yang umum digunakan ialah: autograft (penggantian satu bagian tubuh dengan lainnya dalam satu individu); allograft (penggantian tulang manusia dengan tulang yang berasal dari manusia lain); xenograft (penggantian tulang manusia dengan tulang yang berasal dari hewan); exogemus (penggantian atau implantasi dengan bahan sintetik atau yang biasa disebut dengan biomaterial); dan berbagai macam material sintetik lainnya seperti polimer, material logam, komposit, dan biokeramik. Setiap material tersebut memiliki kekurangan dan kelebihan sebagai material untuk memperbaiki tulang, seperti stabilitas kimia, biokompatibilitas, serta biodegradasi dengan tubuh dalam waktu yang lama. Adanya keterbatasan untuk setiap material tersebut memicu perkembangan riset di bidang biomaterial. ${ }^{5}$

Biomaterial merupakan bahan inert yang diimplantasi ke dalam sistem hidup sebagai pengganti fungsi jaringan hidup atau organ. Pemilihan biomaterial yang tepat sangat diperlukan dalam proses implantasi. Biomaterial yang dipilih ialah yang mudah diperoleh, biokompatibel atau sesuai dengan jaringan keras dalam komposisi dan morfologi kandungannya, bioaktif, dan tidak toksik. ${ }^{5}$

Biokeramik merupakan bahan yang dibentuk dari alumina atau hidroksipatit, dan kalsium fosfat. Sifat-sifat biokeramik antara lain: 1) bioinert, sedikit berinteraksi dengan jaringan sekitarnya, sedikit reaktivitas kimia, dan stabil di dalam tubuh manusia; 2) bioactive, bahan yang memperoleh respon biologi yang menghasilkan pembentukan ikatan antara jaringan dan materi, serta untuk mengisi cacat tulang; 3) bioresorbable, larut dan perlahan-lahan digantikan oleh jaringan baru, serta untuk regenerasi tulang. ${ }^{6}$

Material komposit kalsium fosfat dibutuhkan untuk memperbaiki atau mengganti tulang yang rusak. Senyawa kalsium fosfat terdiri dari hidroksi apatit (HA) yang memiliki formula $\mathrm{Ca}_{10}\left(\mathrm{PO}_{4}\right)_{6}(\mathrm{OH})_{2} \cdot$ sedangkan karbonat apatit adalah hasil substitusi ion karbonat dengan gugus fosfat dari hidroksi apatit. Rumus kimia karbonat apatit ialah $\mathrm{Ca}_{10}\left(\mathrm{PO}_{4} \mathrm{CO}_{3}\right)_{6}(\mathrm{OH})_{2}$ dengan $\mathrm{Ca} / \mathrm{P}$ rasio 1,6-2,0. Karbonat apatit terdiri dari 
kelompok hidroksil (tipe A) dan fosfat (tipe B). Karbonat apatit tipe B terdapat paling melimpah di tulang manusia. Baik hidroksi apatit maupun karbonat apatit memiliki biokompatibilitas yang baik terhadap kontak langsung dengan tulang. Umumnya kalsium fosfat hidroksi apatit digunakan sebagai pengganti cangkok tulang karena sifatnya biokompatibel dan osteokonduktif. 6,7

Tabel 1. Sifat hidroksi apatit dan karbonat apatit ${ }^{6}$

\begin{tabular}{ll}
\hline \multicolumn{1}{c}{ Sifat hidroksi apatit (HA) } & \multicolumn{1}{c}{ Sifat karbonat apatit (CHA) } \\
\hline Material yang tidak menyebabkan reaksi & Material yang tidak menyebabkan reaksi \\
penolakan dari sistem kekebalan tubuh & penolakan dari sistem kekebalan tubuh \\
Mengandung komponen $\mathrm{Ca}^{2+}$ dan $\mathrm{PO}_{4}{ }^{3-}$ & Mengandung komponen $\mathrm{Ca}^{2+}, \mathrm{PO}_{4}{ }^{3-}$ dan $\mathrm{CO}_{3}{ }^{2-}$ \\
Lambat dalam proses pembentukan tulang & Cepat dalam proses pembentukan tulang baru \\
baru & \\
Lambat diserap & Cepat diserap \\
Mengandung unsur kristal yang tinggi & Mengandung unsur kristal yang rendah \\
Disintesis pada suhu dibawah $90^{\circ} \mathrm{C}$ & Disintesis pada suhu dibawah $37^{\circ} \mathrm{C}$ \\
Rasio karbonat terhadap fosfat $1,67$. & Rasio karbonat terhadap fosfat $1,6-2,0$ \\
\hline
\end{tabular}

\section{METODE PENELITIAN}

Jenis penelitian ialah eksperimental observasional dengan menggunakan subyek penelitian 18 ekor tikus putih (Rattus norvegicus) galur Wistar yang berumur 2022 minggu dengan berat badan 350-400 gr. Tikus dipersiapkan dalam kandang dan diberi pakan pellet dan minuman air untuk adaptasi. Setiap tikus ditimbang dan diamati kesehatannya secara fisik. Tikus yang sakit segera diganti dengan tikus baru dengan kriteria yang sama. Tikus dipuasakan 2 jam sebelum operasi dan bulu kepala digunting kemudian dibagi menjadi dua kelompok. Kelompok 1 diberi perlakuan karbonat hidroksi apatit dan plasma kaya trombosit (KHA-PKT) dan diberi nomor 1-9. Kelompok 2 diberi perlakuan hidroksi apatit dan plasma kaya trombosit (HA-PKT) dan diberi nomor 1018. Pada penelitian ini digunakan karbonat apatit yang beredar di Indonesia (GamaCHA) yang merupakan produk hasil penelitian panjang Tim Riset Rekayasa Jaringan Universitas Gadjah Mada dengan Paten Nomor ID P 0036890 yang memperoleh Anugerah Kekayaan Intelektual Luar Biasa Tahun 2014 dan Publikasi Internasional. $^{8}$

Plasma kaya trombosit (PKT) adalah fraksi plasma darah dengan konsentrasi trombosit 3-5 kali di atas nilai normal. ${ }^{9}$

Pembiusan dilakukan dengan penyuntikan ketamin 0,5-1 mg/BB. Darah diambil sebanyak 3 cc intrakardiak, dimasukkan kedalam tabung EDTA, dan dilakukan sentrifugasi selama 10 menit, kemudian dilakukan sentrifugasi ke-2 selama 2 menit. Selanjutnya dilakukan pengambilan plasma kaya trombosit. Kepala tikus didesinfeksi, dilakukan insisi midline dari nasofrontal ke protuberansia osipital eksterna melewati sutura mid sagitalis, diperdalam hingga mencapai tulang, dan dilakukan kraniektomi dengan diameter $3 \mathrm{~mm}$. Pada defek, untuk kelompok 1 diberikan karbonat apatit dan plasma kaya trombosit sedangkan untuk kelompok 2 diberikan hidroksi apatit dan plasma kaya trombosit. Setelah operasi, tikus diberi perlakuan yang sama yaitu dirawat di kandang yang terjaga kebersihannya dan diberi makanan yang sama. Pada minggu ke-2, minggu ke-3 dan minggu ke-4, tikus diterminasi dengan inhalasi overdosis CO2. Dilakukan reinsisi, diamati pertumbuhan jaringan tulang, kalvaria dipotong kemudian difiksasi dengan formalin buffer $10 \%$ dan diproses untuk pembuatan sediaan di Pusat Diagnostik Patologi Anatomi (PDPA) Manado. 


\section{HASIL PENELITIAN}

Penilaian gambaran mikroskopik pertumbuhan tulang kalvaria tikus dilakukan pada minggu ke-2, ke-3, dan ke4. Penilaian tersebut meliputi pertumbuhan sel radang dan pembentukan tulang imatur, dinilai berdasarkan rerata persentase/10 lapangan pandang besar (LPB) (Gambar 1).

Tabel 2 memperlihatkan gambaran pertumbuhan tulang kalvaria tikus pada kelompok 1 (KA-PKT). Pembentukan tulang matur menunjukkan peningkatan bertahap sejak minggu ke-2 s/d ke-4 yang mencapai $45-95 \%$ pada minggu ke-4. Tabel 3 memperlihatkan gambaran pertumbuhan tulang kalvaria tikus pada kelompok 2 (HA-PKT). Pembentukan tulang matur menunjukkan peningkatan yang lebih lambat dibandingkan kelompok 1 dan pada minggu ke-4 hanya mencapai $15-55 \%$.

\section{BAHASAN}

Pada minggu ke-2 (14 hari) setelah perlakuan, terjadi proses pembentukan sel osteoprogenitor berasal dari jaringan ikat mesenkim yang merupakan jaringan penghubung celah yang terjadi pada jaringan rusak atau hilang serta dapat membantu transportasi nutrisi dan peredaran darah yang mempercepat regenerasi jaringan, kemampuan bermitosis sehingga berfungsi sebagai sumber sel baru (proliferasi sel), pengeluaran serotonin yang merangsang hemostasis dan vasokontriksi, dan pengeluaran histamin yang merangsang sel polimorfonuklear $(\mathrm{PMN})$ dan monosit ke tempat luka. ${ }^{10}$

Tabel 2. Penilaian gambaran mikroskopik tulang kalvaria pada tikus kelompok 1 (KHA-PKT)

\begin{tabular}{lcc}
\hline \multicolumn{1}{c}{ Minggu } & $\begin{array}{c}\text { Pertumbuhan } \\
\text { sel radang (\%) }\end{array}$ & $\begin{array}{c}\text { Pembentukan } \\
\text { tulang imatur (\%) }\end{array}$ \\
\hline Minggu ke-2 (14 hari) & 90 & 10 \\
Tikus 1 & 80 & 10 \\
Tikus 2 & 80 & 10 \\
Tikus 3 & & \\
Minggu ke-3 (21 hari) & 80 & 45 \\
Tikus 4 & 80 & 40 \\
Tikus 5 & 80 & 10 \\
Tikus 6 & & \\
Minggu ke-4 (28 hari) & 90 & 80 \\
Tikus 7 & 80 & 90 \\
Tikus 8 & 80 & 45 \\
Tikus 9 & & \\
\hline
\end{tabular}

Tabel 3. Penilaian gambaran mikroskopik tulang kalvaria pada tikus kelompok 2 (HA-PKT)

\begin{tabular}{lcc}
\hline \multicolumn{1}{c}{ Minggu } & $\begin{array}{c}\text { Pertumbuhan } \\
\text { sel radang }(\boldsymbol{\%})\end{array}$ & $\begin{array}{c}\text { Pembentukan } \\
\text { tulang imatur }(\boldsymbol{\%})\end{array}$ \\
\hline Minggu ke-2 (14 hari) & 60 & 5 \\
Tikus 10 & 60 & 5 \\
Tikus 11 & 70 & 5 \\
Tikus 12 & & \\
Minggu ke-3 (21 hari) & 60 & 10 \\
Tikus 13 & 70 & 15 \\
Tikus 14 & 70 & 20 \\
Tikus 15 & & \\
Minggu ke-4 (28 hari) & 20 & 15 \\
Tikus 16 & 70 & 55 \\
Tikus 17 & 30 & 15 \\
Tikus 18 & & \\
\hline
\end{tabular}




\section{Kelompok 1 (KHA-PKT)}

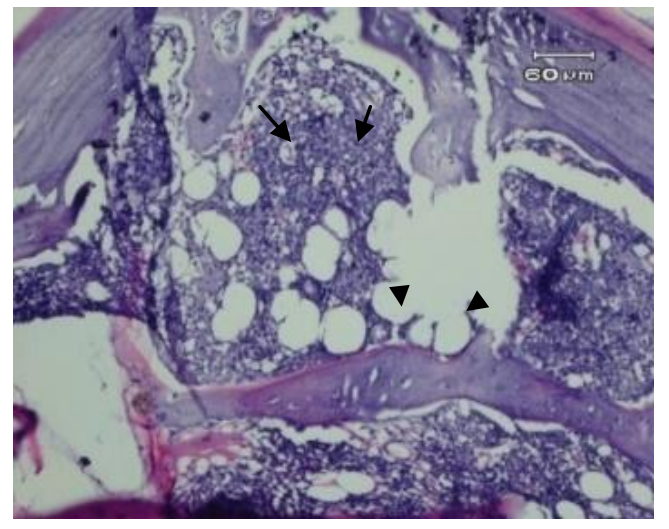

Minggu ke-2

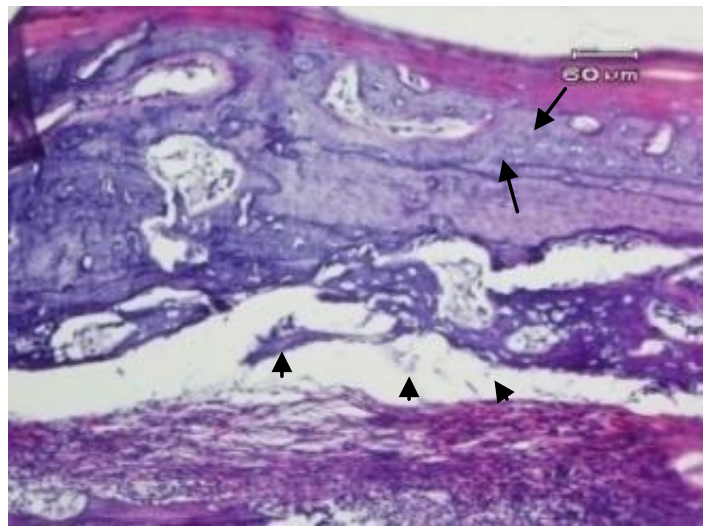

Minggu ke-3

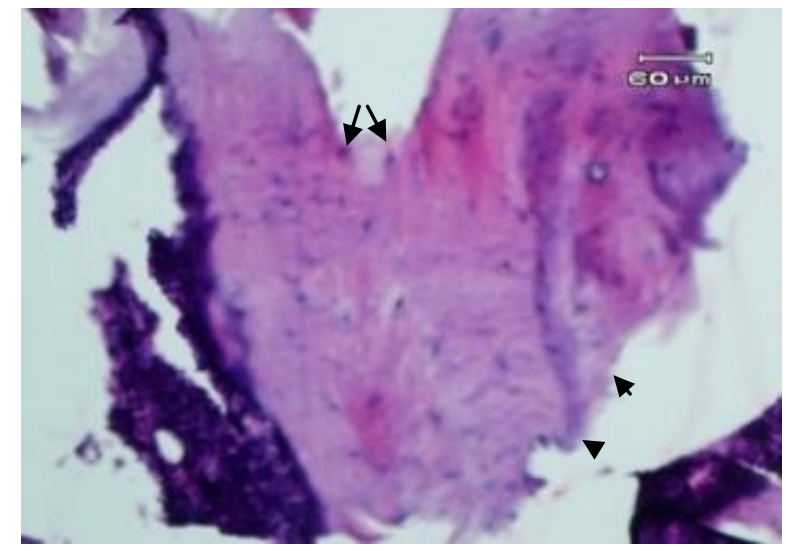

Minggu ke-4
Kelompok 2 (HA-PKT)

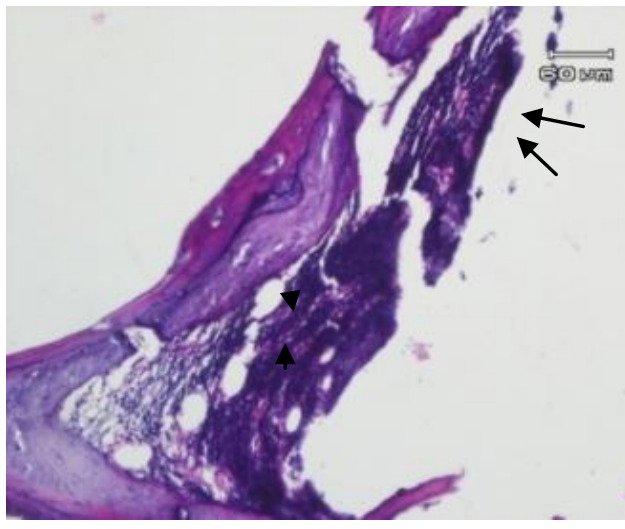

Minggu ke-2

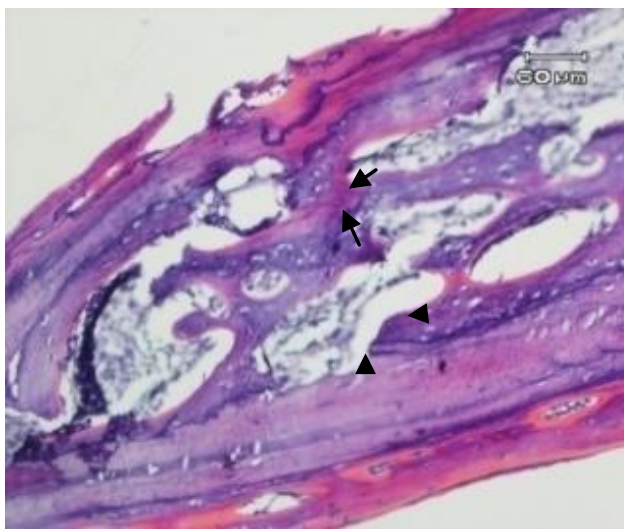

Minggu ke-3

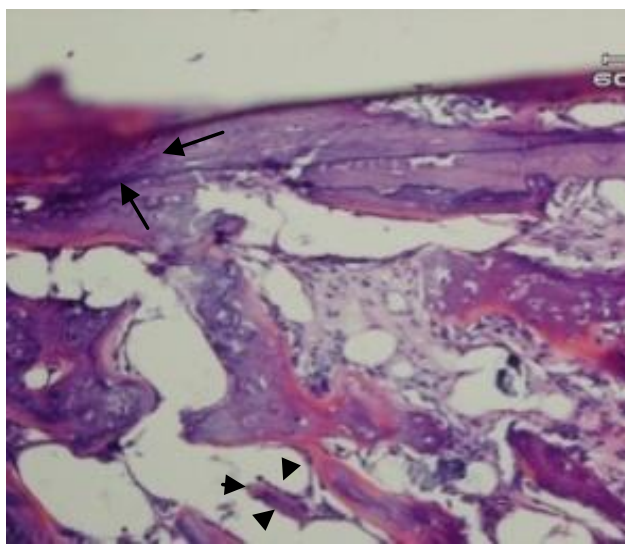

Minggu ke-4

Gambar 1. Histopatologik pertumbuhan tulang kalvaria pada minggu ke-2, ke-3, dan ke-4 untuk kelompok 1 dan 2. Anak panah menunjukkan sel radang (limfosit dan neutrofil); ujung panah menunjukkan tulang imatur

Growth factor akan merekrut sel endotel untuk membuat pembuluh darah baru (angiogenesis), fibroblas terangsang untuk membentuk matriks ekstrasel sehingga luka akan cepat menutup. ${ }^{11}$

Trombosit mengandung lebih dari 30 protein bioaktif yang berupa faktor pertumbuhan, berbagai sitokin, dan 
kemokin yang berperan penting pada proses penyembuhan luka, respons akut jaringan terhadap trauma, serta terlibat pada beberapa proses fisiologis selular, misalnya pertumbuhan, diferensiasi, dan replikasi sel. Sifat plasma kaya trombosit yang autolog membuatnya relatif aman dan tidak berisiko menimbulkan reaksi alergik atau menularkan penyakit. Tingginya konsentrasi trombosit dan berbagai faktor pertumbuhan di dalamnya, telah membuat plasma kaya trombosit dimanfaatkan pada banyak cabang ilmu kedokteran. ${ }^{9}$ Normal trombosit darah berkisar antara $150.000 / \mu \mathrm{L}$ dan $350.000 / \mu \mathrm{L}$ dan rata-rata sekitar $200.000 / \mu \mathrm{L}$ sedangkan plasma kaya trombosit bisa didefinisikan sebagai plasma darah yang mengandung 1.000 .000 trombosit/ $\mu \mathrm{L} .^{12}$

Kandungan plasma kaya trombosit antara lain: berbagai macam faktor pertumbuhan seperti platelet derived growth factor (PDGF), transforming growth factor (TGF), vascular endothelial growth factor (VEGF), basic fibroblast growth factor (BFGF), insulin-like growth factor (IGF-1), interleukin 1, dan interleukin 6 (IL 1, IL6). Kadar growth factor tetap terjaga setelah dilakukan pembuatan plasma kaya trombosit. ${ }^{13}$

Hasil penelitian ini pada minggu ke-2 untuk kelompok 1 (KHA-PKT) terjadi proses infiltrasi sel netrofil dan limfosit sebesar 80-90\% serta pembentukan jaringan tulang imatur sebesar $10 \%$ sedangkan pada kelompok 2 (HA-PKT) terjadi infiltrasi sel netrofil dan limfosit sebesar 60-70\% serta pembentukan jaringan tulang imatur sebesar 5\%. Hasil penelitian ini sejalan dengan penelitian oleh Park et al. ${ }^{6}$ yang menyatakan bahwa pada minggu ke-2 terjadi infiltrasi sel-sel neutofil dan limfosit dan terbentuk jaringan ikat longgar. Hasil penelitian ini juga selaras dengan penelitian oleh Jae et al. ${ }^{14}$ yang menggunakan perlakuan hidroksi apatit dan chitosan fibroin dan melaporkan bahwa terjadi pembentukan tulang imatur (woven bone) pada minggu ke- 2 .

Proses pembentukan tulang diawali oleh proses inflamasi. Pada tingkat seluler, sel-sel inflamasi dan fibroblas akan menginfiltrasi daerah luka. Infiltrasi sel-sel inflamasi bersama dengan osteoblas menyebabkan terbentuknya jaringan granulasi dan meningkatkan pertumbuhan vaskuler serta migrasi sel-sel mesenkim agar area yang mengalami fraktur mendapat cukup oksigen dan nutrisi. Osteoblas merupakan sel pembentuk tulang yang berasal dari sel osteoprogenitor dan ditemukan pada permukaan tulang. Sel ini bertanggungjawab pada pembentukan dan proses mineralisasi tulang. Osteoblas menyintesis kolagen dan glikosaminoglikan dari matriks tulang dan berperan dalam proses mineralisasi tulang. Tulang imatur tampak sebagai anyaman serat kolagen yang tidak teratur, terdiri dari banyak osteosit, dan memiliki kandungan garam mineral yang sedikit sehingga secara fisik jaringan tulang ini tidak kuat. ${ }^{10}$

Pada minggu ke-3 untuk kelompok 1 (KA-PKT) terjadi infiltrasi sel neutrofil dan limfosit sebesar $80 \%$ serta pembentukan jaringan tulang imatur sebesar $10-45 \%$ sedangkan pada kelompok 2 (HA-PKT) terjadi infiltrasi sel neutrofil dan limfosit sebesar 60-70\% serta pembentukan jaringan tulang imatur sebesar 10-20\%. Dalam pembentukan tulang atau dalam proses penyembuhan tulang, maka tulang yang tumbuh pada awal berupa tulang muda atau tulang primer berupa anyaman (woven bone). Susunan tulang ini terbentuk pada saat osteoblas membentuk osteoid secara cepat dan terdiri dari serat kolagen yang tidak teratur pada osteoid, lebih banyak osteosit, tetapi memiliki kandungan garam mineral yang sedikit. ${ }^{10}$

Hasil penelitian ini membuktikan bahwa KHA dan HA berperan dalam proses penutupan defek kalvaria. Hal ini didukung oleh penelitian yang dilakukan Valiense et al. ${ }^{15}$ tentang KHA pada penutupan tulang kepala tikus yang menyatakan bahwa pembentukan tulang imatur terjadi pada minggu ke tiga. Karbonat apatit maupun hidroksi apatit berikatan dengan protein-protein yang diperlukan untuk pembentukan jaringan baru sehingga dapat memicu pertumbuhan 
sel ke jaringan yang diinginkan. Karbonat apatit maupun hidroksi apatit juga memacu pertumbuhan tulang baru, serta mempercepat proses proliferasi dan diferensiasi osteoblas.

Pada minggu ke-4 untuk kelompok 1 (KHA-PKT) didapatkan infiltrasi sel neutrofil dan limfosit sebesar $80-90 \%$ serta pembentukan jaringan tulang imatur sebesar $45-90 \%$ sedangkan untuk kelompok 2 (HA-PKT) infiltrasi sel neutrofil dan limfosit sebesar $20-70 \%$ serta pembentukan jaringan tulang imatur sebesar $15-55 \%$. Hasil tersebut memperlihatkan bahwa KHA lebih baik dibandingkan HA dalam pembentukan tulang imatur.

Dibandingkan dengan hidroksi apatit (HA), karbonat apatit (KHA) memiliki keunggulan sifat dalam kaitannya dengan proses remodeling tulang, yaitu: ${ }^{8,16}$

1. Karbonat apatit merupakan komposisi pada tulang manusia sedangkan hidroksi apatit bukan merupakan komposisi tulang manusia.

2. Karbonat apatit dapat diresorbsi dengan baik oleh osteoklas sedangkan hidroksi apatit tidak dapat diresorbsi.

3. Karbonat apatit memiliki kemampuan kelarutan yang baik pada kondisi asam lemah yaitu saat osteoklas bekerja meresorbsi tulang dengan mengeluarkan ion $\mathrm{H}^{+}$

4. Karbonat apatit dapat memacu pertumbuhan tulang secara sempurna sedangkan hidroksi apatit memacu pertumbuhan tulang lebih lambat.

Keunggulan karbonat apatit dibandingkan hidroksi apatit mendukung hasil penelitian ini yang mendapatkan bahwa KHA lebih baik dibandingkan HA dalam pembentukan tulang imatur.

Bone graft telah digunakan dalam proses operatif pada pasien dengan kerusakan jaringan tulang. Pada jaringan tulang yang mengalami kerusakan, diperlukan suatu perancah yang akan berfungsi sebagai pengganti lingkungan mikro yang hilang selama proses kerusakan/kehilangan jaringan tulang. Dengan fungsi memberikan lingkungan mikro yang sesuai dengan jaringan yang hilang, maka bone graft yang tepat akan membantu terjadinya rekruitmen sel dan menjadi penghubung celah yang terjadi pada jaringan yang rusak atau hilang sehingga dapat membantu transportasi nutrisi, peredaran darah dan zat-zat lain yang diperlukan untuk percepatan regenerasi jaringan. Bone graft yang baik harus dapat diterima oleh tubuh, tidak menimbulkan reaksi toksisitas serta hipersensitivitas; oleh karena itu bone graft harus identik dengan jaringan tulang asli pada tubuh manusia. Disamping itu, bone graft yang baik harus dapat diresorbsi oleh osteoklas dengan tingkat yang sesuai dengan kecepatan remodeling tulang. ${ }^{7,8,16}$

Pada penelitian ini digunakan karbonat apatit Gama-CHA yang merupakan produk hasil penelitian panjang Tim Riset Rekayasa Jaringan Universitas Gadjah Mada dengan Paten Nomor ID P 0036890. Gama-CHA adalah suatu bone graft (material pengganti) tulang yang diproduksi secara biomimetis (sesuai dengan kondisi fisiologis tubuh) dan identik dengan tulang asli manusia. GamaCHA mengandung karbonat apatit serta polimer berupa kolagen terdenaturalisasi yang berfungsi untuk mempercepat proses regenerasi jaringan tulang, memiliki sifat osteokonduksi, osteoinduksi, dan osteogenesis. Karbonat apatit merupakan komponen utama pada tulang manusia yang diproduksi secara sintesis tetapi identik (sama dan sebangun) sehingga dapat menghindari reaksi imunologis yang sering terjadi bila menggunakan allograft maupun xenograft. Cara memroduksi Gama-CHA dilakukan pada suhu dan kondisi biomimetis (sesuai dengan kondisi fisiologis pada tubuh manusia) sehingga menghasilkan karbonat apatit yang memiliki kristalinitas rendah yang identik dengan apatit pada manusia dan memiliki kadar $\mathrm{Ca} / \mathrm{P}$ yang sama dengan kadar $\mathrm{Ca} / \mathrm{P}$ pada tulang manusia. ${ }^{8}$

Cara produksi Gama-CHA yang tidak menggunakan bahan kimiawi selain yang ada pada tulang manusia menyebabkan Gama-CHA unggul dari segi keamanan dan identik dengan tulang manusia sehingga 
menjamin keberhasilan perawatan. GamaCHA didesain agar memungkinkan osteoblas berproliferasi di daerah yang mengalami luka/hilang, dan menyaring selsel yang tidak diinginkan. ${ }^{8}$

Gama-CHA telah terdaftar secara resmi di Kementerian Kesehatan Republik Indonesia dengan nomor Sertifikat Izin Edar Kemenkes RI No. Akd 20602410125. Keamanan Gama-CHA terjamin karena telah memenuhi persyaratan untuk mendapatkan izin edar. ${ }^{8}$

\section{SIMPULAN}

Dari hasil penelitian terhadap proses penutupan defek kalvaria dengan perlakuan karbonat apatit dan hidroksi apatit disertai pemberian plasma kaya trombosit dapat disimpulkan bahwa berdasarkan gambaran histopatologik terdapat pembentukan tulang imatur yang lebih banyak pada pemberian karbonat apatit dibandingkan pemberian hidroksi apatit.

\section{DAFTAR PUSTAKA}

1. Japardi I. Buku Cedera Kepala. Jakarta: Bhuana Ilmu Populer, 2004; p. 3-8.

2. ATLS. Student Course Manual (8th ed). 2008. American College of Surgeons Committee on Trauma. xxxi-xxxiiip.

3. Greenberg SM. Chapter 23-24. Handbook of Neurosurgey (6th ed). New York: Thieme Medical Publishers, 2006; p. 612, 632-78.

4. Elephterios B, Dobrin N, Chiriac A. Titanium mesh cranioplasty for patients with large cranial defects - tehnical notes. Romanian Neurosurg. 2010;XVII(4):456-60.

5. Ning L, Malmstrom H, Ren FY. Porous collagen hydroxyapatite scaffolds with mesenchymal stem cells for bone regeneration. JOI. 2015;41(1):45-9.

6. Park YJ, Yang C, Jung IH, Lim HC, Lee YS, Jung UW, et al. Regeneration of rabbit calvarial defects using cells implanted nano-hydroxyapatite coated silk scaffold. Biomater Res. 2015;19:110.

7. Wang YS. Sol-gel derived hydroxyapatite coatings on metallic implants. Biological and Biomedical Coating
Handbook: Applications. CRC Press Taylor \& Francis Group, 2011; p. 1-45.

8. Ana ID, Matsuya S, Ishikawa K. Engineering of carbonate apatite bone substitute based on composition-transformation of gypsum and calcium hydroxide. Engineering. 2010;2:344-52.

9. Pietrzak SW, Eppley LB. Platelet rich plasma: biology and new technology. J Craniofac Surg. 2005;16(6):1043-54.

10. Rasjad C. Buku Pengantar Ilmu Bedah Ortopedi. Makassar: Universitas Hasanuddin, 2000; p. 399-401.

11. Rodriguez IA, Kalaf, EAG, Bowlin GL, Sell SA. Platelet-rich plasma in bone regeneration: Engineering the Delivery for Improved Clinical Efficacy. BioMed Resarch International. 2014(2014):1-15. Article ID 392398.

12. Amable PR, Carias RBV, Teixeira MVT, da Cruz Pacheco I, do Amaral RJFC, Granjeiro JM, et al. Platelet rich plasma preparation for regenerative medicine: Optimization and quantification of cytokines and growth factors. Stem Cell Res Ther. 2013:4(3):67.

13. Civinini R, Macera A, Nistri L, Redl B, Innocenti M. The use of autologous blood derived growth factors in bone regeneration. Clin Cases Miner Bone Metab. 2011;8(1):25-31.

14. Jae MS, Sang HS, Yong DK, Jae YL, Young JB, Sang YY, et al. Comparative study of chitosan/fibroinhydroxyapatite and collagen membranes for guided bone regeneration in rat calvarial defects: micro-computed tomography analysis. Int J Oral Sci. 2014;6(2):87-93. doi: 10.1038/ijos.2014.16.

15. Valiense H, Fernandes GVO, Moura B, Calasans-Maia J, Alves A, Rossi AM, et al. Effect of carbonate-apatite on bone repair in non-critical size defect of rat calvaria. Bahiana School of Medicine and Public Health, Brazil. Key Engineering Materials. 2012;493494:258-262.

16. Fleet ME, Liu Xiaoyang, Liu Xi. Orientation of channel carbonate ions in apatite: Effect of pressure and composition. American Mineralogist. 2011;96:1148-57. 